\title{
Number of Stock Plant Shoot Nodes Influences splitting of 'Lilo' Poinsettia
}

\author{
Stephen A. Carver ${ }^{1}$ and
}

Harry K. Tayama ${ }^{2}$

Additional index words. Euphorbia pulcherrima, juvenility, maturity, floral induction

Summary. The influence of poinsettia (Euphorbia pulcherrima Wild. ex Klotzsch) stock plant shoot maturity on subsequent splitting of cuttings taken from the shoots was evaluated. Terminal cuttings $(7.5 \mathrm{~cm})$ taken from 'Lilo' poinsettia stock plant axillary shoots that had 4,8 , or 12 nodes were rooted, planted, then observed for initial signs of splitting (conversion of the vegetative terminal buds into floral buds). The percentages of cuttings that split were 22,77 , and $\mathbf{1 0 0}$ for those taken from shoots with 4,8 , and 12 nodes, respectively. By implication, cuttings should be taken just as stock plant axillaries reach a size adequate for propagation to help reduce the incidence of splitting.

$\mathrm{S}$ plitting is a common, often economically significant physiological problem of poinsettia, in which the desirable, naturally occurring, single-stemmed vegetative growth habit is destroyed. It occurs when the terminal vegetative bud is transformed into a reproductive bud under normally noninductive long-day

${ }^{1}$ Research Associate

${ }^{2}$ Professor.

Department of Horticulture, The Ohio State University, 2001 Fyffe Court, Columbus, OH 43210.

Salaries and research support provided by state and federal funds appropriated to the Ohio Agricultural Research and Development Center, The Ohio State University. Manuscript no. 147-91. We thank Paul Ecke Poinsettias, Encinitas, Calif., for their donation of rooted poinsettia cuttings, and Grace/Sierra Co., Fogelsville, Pa., for their donation of Metro-Mix 350 growing medium and Osmocote 19N-2.6P-9.9K. Mention of a trade name does not constitute a guarantee of the product or an endorsement by The Ohio State Univ. over other products not mentioned. 
conditions. Induction is followed by the development of vegetative shoots (usually three) just below the terminal flower bud, resulting in a "splitting" of the main stem. Splitting (more specifically, flower bud induction) of vegetative poinsettia stems has been closely and positively correlated to the mature developmental phase (Siraj-Ali et al., 1990b).

Poinsettias exhibit distinguishable physiological or developmental phases. As the vegetative stem grows and elongates, the terminal, though the youngest portion of the stem, becomes progressively more mature in character (Poethig, 1990; Siraj-Ali et al., 1990a). Many workers, including Seeley (1988) and Larson (1990), have observed that as poinsettia stems elongate, they become more prone to splitting. It would appear that at some point a certain level of maturity is reached, triggering flower induction. However, without required short-day conditions for continued flower bud development, vegetative growth (i.e., axillary shoots) resumes and the flower bud aborts. One might expect that mature terminal cuttings taken from elongated, many-noded shoots also would be more prone to splitting than juvenile, terminal cuttings taken from shorter, younger shoots. However, we found no documentation supporting this hypothesis. This study was designed to assess the influence of stock plant shoot growth (i.e., number of nodes) on subsequent splitting of cuttings.

Rooted cuttings of 'Eckespoint Lilo' were received on 12 May 1988 and were planted in 0.5-liter clay pots filled with Metro-Mix 350 (Grace/ Sierra, Fogelsville, Pa.) growing medium. They were topdressed with 2.4 g Osmocote $19 \mathrm{~N}-2.6 \mathrm{P}-9.9 \mathrm{~K} / \mathrm{pot}$, placed under intermittent mist, and maintained under $21 \mathrm{C}$ nights. Four days later, they were removed from the mist and placed in an 18C night, whitewashed greenhouse shaded with $60 \%$ Saran cloth. The Saran was removed 1 week later. The plants were irrigated as required with $200 \mathrm{ppm} \mathrm{N}$ from Peter's 20N-4.3P-16.6K (Grace/Sierra) at every irrigation. Stock plants were pinched to eight leaves (nodes) when roots had grown to the bottom and sides of the container, 3 weeks after panning (plant- ing), and then were transplanted to 1.5-liter plastic pots 1 week later. Subsequent pinching was performed on a variable basis to allow adequate numbers of shoots with 4,8 , or 12 nodes to develop by 15 Aug. Cuttings $(7.5 \mathrm{~cm}$ long, a commercial standard) were harvested 15 Aug., stuck in plastic net pots filled with Metro-Mix 350, and placed in a $21 \mathrm{C}$ night greenhouse under intermittent mist for 3 weeks. Rooted cuttings were planted one per 1.5-liter plastic pot filled with MetroMix 350. Osmocote (19N-2.6P$9.9 \mathrm{~K})$ was topdressed at a rate of 4.8 g/pot. Shading, night temperatures, and irrigation were at the levels and durations noted above. Chlormequat (1500 ppm) was applied as a spray to plants on 19 Sept. and 3 and 17 Oct.). The plants were observed three to four times per week for incidence of splitting. There were three treatments (4, 8 , and 12 nodes), three replications per treatment, and three plants per replication. The data violated the assumptions of the analysis of variance (all plants in one treatment split-no variance for that treatment) and, therefore, were analyzed via the KruskalWallis and Mann-Whitney nonparametric tests (Meddis, 1975).

There was an average of 19 days from planting to splitting, with a range from 17 to 22 days. There was a significant increase in splitting of plants as the stem node number of the stock plant from which they were taken increased from four to 12 . (Table 1). The largest portion of that increase occurred between cuttings taken from four- and eight-node shoots.

Increased splitting associated with stem growth was the expected outcome and is consistent with the welldocumented observation that terminals ofintact, elongated, many-noded stems are prone to splitting. The maturity level of the stem terminal at the time of cutting appears to exert a determining influence on subsequent induction of the terminal vegetative bud and stem-splitting. Although it may have a rejuvenating effect on the remaining portion of the shoot, cutting removal (i.e., removal of the more mature terminal growth, leaving the more juvenile basal stem portion) has no observable rejuvenating effect on the cutting itself. Therefore, cuttings taken from elongated, many-noded axillaries are more mature and more prone to splitting than cuttings taken from shorter axillaries with fewer nodes.

The natural extension of this study is that cuttings to be taken for finished 'Lilo' poinsettia plants should be taken from stock plants either as or shortly after they reach an adequate size for propagation. Taking cuttings from more mature shoots increases the subsequent risk of splitting.

\section{Literature Cited}

Larson, R.A. 1990. Physiological disorders, p. 22-26. In H.K. Tayama (ed.). Tips on growing poinsettias. 2nd ed., Ohio Coop. Ext. Bul. FP-764.

Meddis, R. 1975. Statistical handbook for non-statisticians. McGraw Hill, New York.

Poethig, S.R. 1990. Phase change and the regulation of shoot morphogenesis in plants. Science 250:923-930.

Seeley, J.G. 1988. Physiological disorders, p. 22-26. In H.K. Tayama (ed.). Tips on growing poinsettias. Ohio Coop. Ext. Bul. FP-764.

Siraj-Ali, Y.S., H.K. Tayama, T.L. Prince, and S.A. Carver. 1990a. Identification of the developmental phases in poinsettia. J. Amer. Soc. Hort. Sci. 115:728-731.

Siraj-Ali, Y.S., H.K. Tayama, T. L. Prince, and S.A. Carver. 1990b. The relationship between maturity level and splitting in poinsettia. HortScience 25:1616-1618.

Table 1. Percent of cuttings taken from stock plant shoots with 4, 8, or 12 nodes that exhibited splitting.

\begin{tabular}{lc}
\hline Treatment & Percent split $^{2}$ \\
\hline Cuttings from stems with four nodes & $22 \mathrm{a}$ \\
Cuttings from stems with eight nodes & $77 \mathrm{~b}$ \\
Cuttings from stems with 12 nodes & $100 \mathrm{~b}$ \\
\hline
\end{tabular}

Percent of nine total plants per treatment. Overall analysis by $K-W$ nonparametric test. Mean separation by $M-W$ nonparametric test at the $5.0 \%$ level. 